\title{
Improving water use efficiency on irrigated dairy farms in Canterbury
}

\author{
R.J. MARTIN ${ }^{1}$, S.M. THOMAS ${ }^{1}$, D.R. STEVENS ${ }^{2}$, R.F. ZYSKOWSKI ${ }^{1}$, D.J. MOOT ${ }^{3}$ and T.J. FRASER ${ }^{4}$. \\ ${ }^{1}$ Crop \& Food Research, Private Bag 4704, Christchurch \\ ${ }^{2}$ AgResearch, Invermay Agricultural Centre, PB 50034, Mosgiel \\ ${ }^{3}$ Agriculture and Life Sciences Division, P.O. Box 84, Lincoln University \\ ${ }^{4}$ AgResearch, Canterbury Agriculture and Science Centre, P.O.Box 60, Lincoln \\ martind@crop.cri.nz
}

\begin{abstract}
Water Use Efficiency (WUE) is an important performance indicator of sustainable production, widely used overseas. WUE is defined in a number of ways, and it is important to know what definition is being used. Overseas data show that WUE on dairy farms depends on both the efficiency of applying water to the paddock, and the efficiency of feed utilisation off the paddock. Pasture WUE requires measurements of the amount of water applied and the amount of pasture produced, which are rarely concurrently measured on dairy farms. Estimates of pasture WUE from previous research experiments are highly variable because of uncertainties about how much water was applied. We have suggested a benchmark for WUE based on measurements on commercial dairy farms, and suggest some ways that farmers can improve their irrigation practices.
\end{abstract}

Keywords: water use efficiency, pasture yield, irrigation, evapotranspiration

\section{Introduction}

Dairy production is increasing rapidly on the Canterbury Plains and in other eastern areas of New Zealand where evapotranspiration from pasture frequently exceeds rainfall and limits soil water supply. In Canterbury, the area of dairy pasture under irrigation increased four fold between 1985 and 1999 to $34 \%$ of the total irrigated area in Canterbury (Doak et al. 2004).

In recent years, there has been growing awareness that water resources in Canterbury are finite (Morgan et al. 2002) and that there are multiple demands on this water resource (Ministry for the Environment 2004). Environment Canterbury (ECan), the regional council with the largest amount of actual and potentially irrigable land in New Zealand, is charged under the Resource Management Act with managing the competitive demands for the use, development and protection of the region's water resources. Miller and Veltman (2004) stated that efficient resource use is an important consideration in the proposed ECan National Resources Regional Plan. Those issued with consents to take water for irrigation are required by the consent to use the water efficiently. The dairy industry itself has set a 10 year target of improving water use efficiency by $40 \%$ (Dairy Environment Review Group 2006). But what does using water efficiently (WUE) mean for dairy farmers, and how can it be applied on farm?

\section{What is WUE?}

WUE has been defined in a number of ways, either in agronomic, economic or engineering based terms (Tanner \& Sinclair 1983), and different authors use the most suitable definition for their purpose.

The classic agronomic or physiological definition of crop WUE is the ratio of the amount of biomass produced to the actual amount of water evaporated and transpired (AET) by that crop (Viets 1962). As AET is difficult to measure, this is often modified to the ratio of biomass production to potential evapotranspiration (PET), the estimated evapotranspiration from a short grass sward with no soil moisture limitation.

Engineers define irrigation WUE as the ratio of water beneficially used to irrigation water delivered to the field. They also use another efficiency measure - irrigation application efficiency (IAE), which is the ratio of water stored in the root zone to the amount delivered to the field (On-Farm Irrigation Committee of the Irrigation and Drainage Division 1978). IAE is affected by distribution uniformity (DU), a measure of the evenness of water application. DU for sprinkler systems is a function of irrigator design, system pressure, water volume, time, topography and wind. For surface irrigation schemes, DU is a function of border length, width, gradient, surface roughness and water flow. For a more detailed explanation of irrigation efficiency definitions, see Aqualink (2006).

From an economic or farm management perspective, WUE is often defined as the ratio of a marketable unit of yield per unit of water used, e.g. $\mathrm{kg}$ of wheat grain or milk solids (MS)/mm (Jensen et al. 1990). Water used can refer either to the amount of irrigation water supplied to a farm, or to the amount of irrigation or irrigation plus rainfall applied to a paddock. The unit of time can also vary between studies - per day, year, season, irrigation season or cutting interval (e.g. Bethune \& Wang 2004; Armstrong et al. 2004). 
How does WUE apply to dairy farming in New Zealand?

Wells \& Barber (1998) and McIndoe (1999) collected milk production and irrigation data from farms, which showed that, on sprinkler irrigated farms, WUE was around $0.2 \mathrm{~kg} \mathrm{MS} / \mathrm{m}^{3}$ of irrigation water applied, compared to $0.04 \mathrm{~kg} \mathrm{MS} / \mathrm{m}^{3}$ on border dyked farms

However, data derived from a more detailed comparison of dairy farms under various forms of irrigation (Greer 1999) showed no consistent relationship between milk solids production and either the amount of irrigation applied or the expected relative efficiency of the different irrigation methods (Fig. 1). For example, sprinklers and border systems had similar efficiencies, irrespective of the amount of water applied, wild flooding had similar WUE to borders and sprinklers, and the two guns had amongst the highest recorded WUE.

In Australia, various studies have quantified production-based WUE for dairy pastures in northern Victoria and southern New South Wales (e.g. Armstrong et al. 2000; Linehan et al. 2004; Armstrong 2004). WUE, on a whole farm scale and measured as kg milk solids/ mega litre of water ( $\mathrm{kg} \mathrm{MS} / \mathrm{ML})$ supplied to the paddock as rainfall or irrigation, ranged from 22 to $124 \mathrm{~kg} \mathrm{MS} /$ ML of water supplied.

Armstrong et al. (2000) found that, compared with low WUE farms, high WUE farms had the same milk production but used less water ( 387 v. $572 \mathrm{ML}$ ), less land (42 v. $83 \mathrm{ha})$ and had a similar number of cows. High WUE farms also had higher estimated pasture consumption/ha (11.5 v. 5.5 t DM/ha), higher milk production/cow (396 v. $277 \mathrm{~kg} \mathrm{MS}$ ), higher stocking rates (3.2 v. 1.8 cows/ha), higher $\mathrm{N}$ fertiliser use ( $59 \mathrm{v}$.
$18 \mathrm{~kg} \mathrm{~N} / \mathrm{ha}$ ) and directed a higher proportion of the estimated energy consumed by cows into milk production (53 v. 46\%). Armstrong (2004) estimated that utilising more of the pasture grown under irrigation on a study farm would increase WUE from 84 to $105 \mathrm{~kg}$ MS/ML of water.

These Australian studies show that WUE, when measured as MS/ML, has two components: the supply and utilisation of the water to grow the feed, and then the management and utilisation of the feed grown. Both of these can vary considerably, and sub-optimal grazing management can nullify any improvement in WUE.

This study has been restricted to the first component, i.e. how much feed can be grown per unit of water used. This potential pasture production WUE can then be adapted by dairy farmers to their particular farm situation. To determine benchmark values for this WUE, we need data on pastures yields, and the amount of water applied to achieve that yield.

\section{Pasture production WUE in New Zealand}

Our initial approach was to find data from New Zealand dairy farms that included measurements of pasture production and the amount of water applied. Unfortunately, attempts to get measurements of both water and pasture data from individual farms proved unsuccessful.

We did, however, find data sets from AgResearch's Winchmore Research Station that were suitable for calculating pasture production WUE. Pasture growth trials under border dyke flood irrigation and either sheep grazing or mowing regimes have been performed at Winchmore for the past 50 years. We have confidence in

Figure 1 Effect of amount of irrigation water applied and type of irrigation system on milk solids (MS) production in Canterbury (data from Greer 1999).

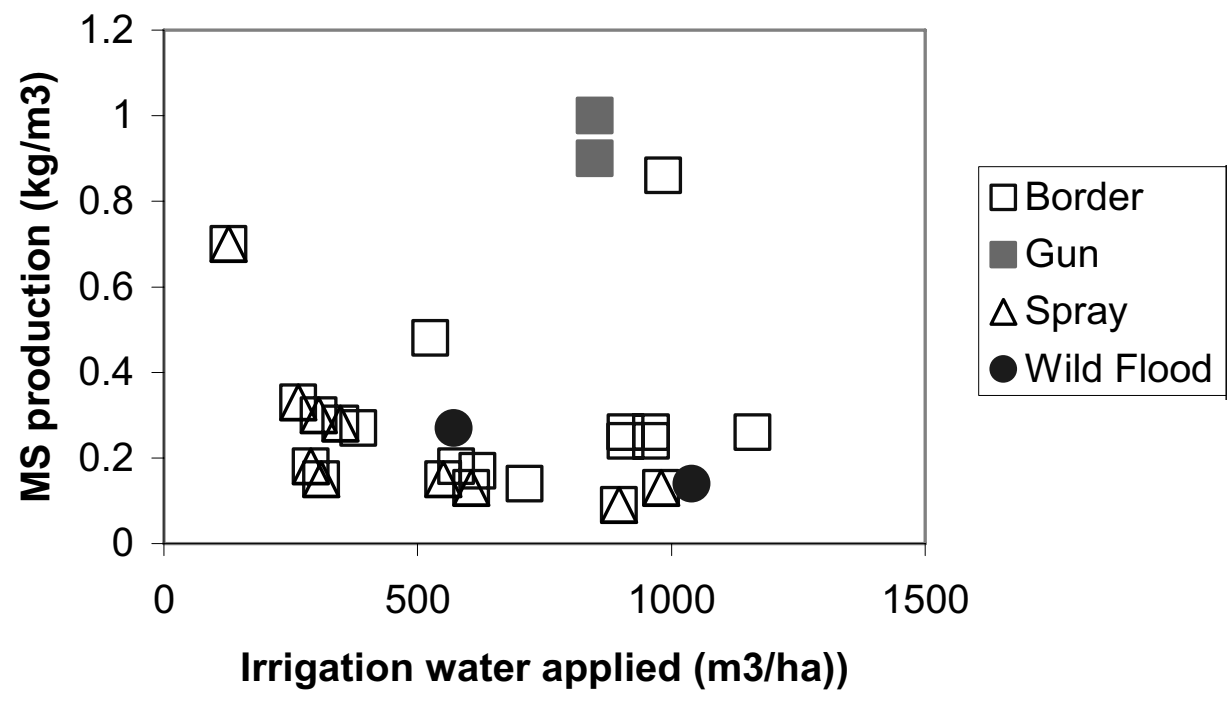


Table 1 Maximum, mean and minimum water use efficiency (WUE) in kg dry matter ha/mm of water applied and maximum annual pasture dry matter production ( $\mathrm{t} / \mathrm{ha}$ ) over the 25 year period 1962-3 to 1984-5 (using data from Rickard \& McBride 1986). ASM is available soil moisture (field capacity minus wilting point), and the \% number is the percent ASM at which the treatment was irrigated. The "every 21 days" treatment simulates the irrigation scheme water roster.

\begin{tabular}{lccccc}
\hline & Dry land & $10 \%$ ASM & $15 \%$ ASM & $20 \%$ ASM & Every 21 days \\
\hline Maximum WUE & 17.0 & 16.4 & 16.2 & 11.5 & 12.3 \\
Mean WUE & 12.3 & 12.4 & 11.4 & 9.2 & 9.6 \\
Minimum WUE & 7.0 & 8.0 & 8.3 & 6.8 & 7.2 \\
Maximum yield & 9.8 & 12.8 & 13.2 & 13.6 & 13.4 \\
\hline
\end{tabular}

Table 2 Yield (t DM/ha), number of irrigations and WUE (kg DM/mm applied) of ryegrass-white clover pasture and lucerne averaged over three soil types in Canterbury using data from Hayman \& McBride (1984). ASM is available soil moisture.

\begin{tabular}{llccccc}
\hline & & Dry land & $\begin{array}{c}\text { Irrigated at } \\
-10 \% \text { ASM }\end{array}$ & $\begin{array}{c}\text { Irrigated at } \\
\text { 0\% ASM }\end{array}$ & $\begin{array}{c}\text { Irrigated at } \\
25 \% \text { ASM }\end{array}$ & $\begin{array}{c}\text { Irrigated at } \\
50 \% \text { ASM }\end{array}$ \\
\hline \multirow{2}{*}{ Pasture } & Yield & 6.4 & 9.2 & 10.7 & 11.3 & 11.8 \\
& Irrigations & & 2.7 & 3.7 & 5.8 & 8.5 \\
& WUE & 12.9 & 11.9 & 12.1 & 10.5 & 8.5 \\
Lucerne & Yield & 9.7 & 11.2 & 12.0 & 12.9 & 13.5 \\
& Irrigations & & 2.2 & 3.4 & 4.8 & 8.7 \\
& WUE & 18.0 & 15.0 & 14.3 & 11.9 & 9.6 \\
\hline
\end{tabular}

the pasture production and rainfall measurements from Winchmore, but are less confident about the irrigation applications, which were assumed to be what the trial borders were designed to apply. In addition, the depth of water applied on a border can vary considerably between irrigations, depending on factors such as water flow and pasture height (Moss et al. 1996).

However, we have calculated WUE from the ryegrasswhite clover pasture yield, rainfall, irrigation dates and designated water application on a long-term irrigation trial at Winchmore (Rickard \& McBride 1986). A summary of 25 years data from selected treatments from this trial is given in Table 1, which shows that WUE ranged from 7 to $17 \mathrm{~kg} \mathrm{DM} / \mathrm{ha} / \mathrm{mm}$, and that there was a two fold variation in WUE within treatments, which was not related to rainfall. Table 1 also shows that the minimum WUE did not differ between treatments, but the mean and maximum WUE increased with decreasing water application. So to achieve maximum WUE, you would not irrigate at all, but this is at the cost of pasture productivity.

Calculations using other New Zealand research data (e.g. Cossens 1982; Martin 1990; Paton \& Greenwood 1994) show pasture WUE can range from 0.7 to $21.7 \mathrm{~kg}$ $\mathrm{DM} / \mathrm{mm}$ of water used. The very low values in some of these trials are likely to be a result of excessive water applications being lost to drainage.

WUE varies between pasture species. Hayman \& McBride (1984) carried out irrigation trials at a number of Canterbury locations with contrasting soil types. At three of their sites, data were recorded for both grass- based pasture and lucerne. The 5 year means for selected treatments at these sites are presented in Table 2. Lucerne received slightly fewer irrigations than pasture, but yielded around $13 \%$ higher under the top three irrigation treatments, and up to $50 \%$ more yield without irrigation, with correspondingly higher WUEs.

\section{Benchmarking pasture production WUE on irrigated dairy farms in New Zealand}

A WUE benchmark will enable dairy farmers to determine how efficiently their irrigation system and irrigation management is converting water to forage. Inefficient use of water wastes scarce water and time, and expensive electricity, and has the potential to increase nutrient leaching.

Our approach to determining a benchmark WUE was to measure pasture production under non limiting conditions on commercial dairy farms in Canterbury. During the 2005-6 season, we measured pasture production in paddocks on six dairy farms in Canterbury, the Lincoln University Dairy Farm and five farms being monitored as part of an associated project funded by the MAF Sustainable Farming Fund. Pasture production was measured using cages or electric tape which were mown and moved after each grazing, using the frame technique of Lynch (1966). Potential evapotranspiration was calculated from weather data collected at the Broadfield meteorological station, using the method of Penman (1948).

Cumulative measured pasture yields are plotted against cumulative Penman PET in Figure 2. Under well 
Figure 2 Cumulative dry matter yield per hectare versus cumulative Penman potential evapotranspiration from the four highest yielding monitored grazed dairy paddocks ( $\boldsymbol{\Delta}$, slope 19.6, $\left.\mathrm{r}^{2} \mathbf{0 . 9 6}\right)$ and from the other monitored paddocks (ם).

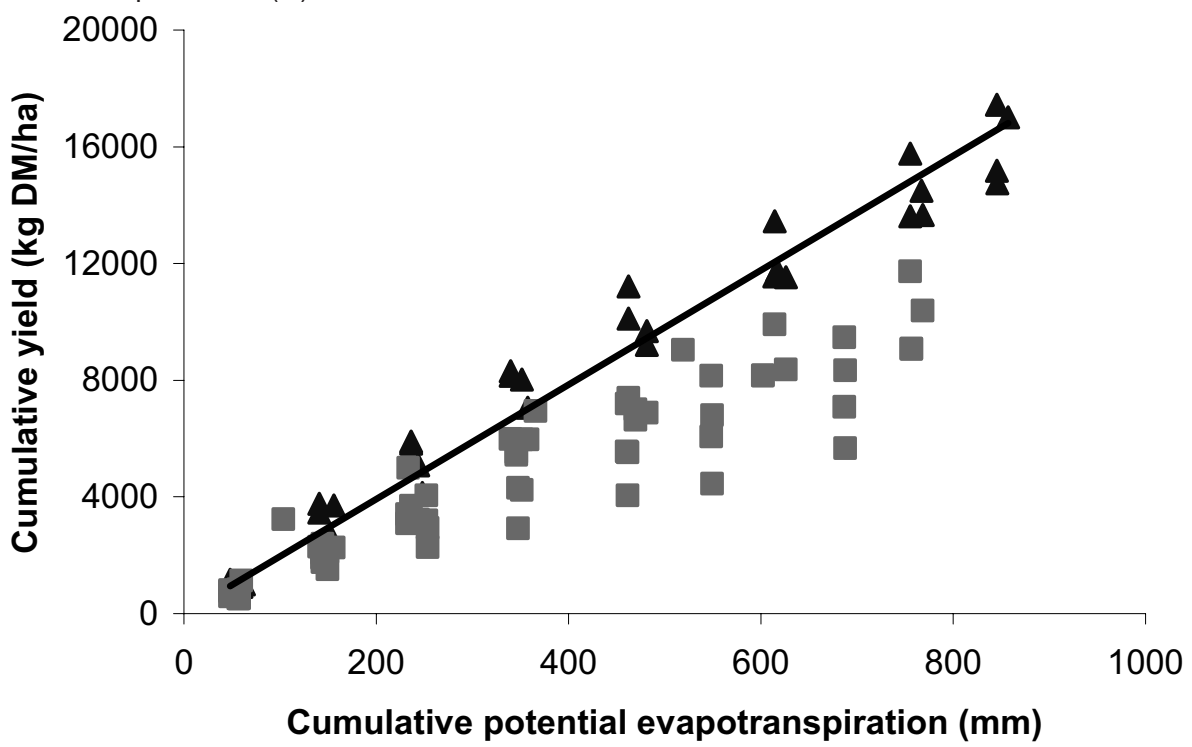

watered conditions, PET from a dairy pasture should equal AET (Penman 1948). In the four highest yielding paddocks, with frequent and relatively uniform irrigation, $1 \mathrm{~mm}$ of Penman PET produced nearly $20 \mathrm{~kg}$ $\mathrm{DM} / \mathrm{ha}$. This was achieved under three centre pivots and one rotorainer.

We suggest that, on the limited data so far available, a WUE of $20 \mathrm{~kg} \mathrm{DM} / \mathrm{mm}$ of Penman PET is a reasonable benchmark for efficiently irrigating grass based pastures on dairy farms in Canterbury. This value is considerably higher that most WUE estimates based on the previous experimental data mentioned above, a reflection of the higher productivity of current pasture species under modern pasture management on Canterbury dairy farms. However, this value may need adjusting if quadrat yields are found not to be representative of overall paddock or farm pasture yields (Woodward \& Rollo 2002).

Putting this numerical value on WUE will enable farmers and Regional Councils to determine how much water is needed to maintain pasture production under various rainfall and irrigation water availability scenarios, given the inherent irrigation application efficiency of the farm's irrigation system.

\section{How can farmers increase their WUE?}

Figure 2 shows that the WUE of the other monitored paddocks in 2005-6 paddocks was well below the regression line, and demonstrates how much WUE can be decreased by irrigation systems with low inherent irrigation application efficiencies or by sub-optimal irrigator operating practices. Dairy farmers can improve their irrigation practices, and hence the amount of pasture produced per mm of water applied, in a number of ways.

Applying water more evenly. They can check whether their irrigation system is applying water evenly. There are consultants who will assess the performance of an irrigation system, but farmers can do simple checks for themselves using catch cans. If applications are more uneven than the system design specifications, modifications to the system may be needed to rectify the situation.

Avoiding over-application of irrigation. Farmers can ensure that water is not being applied faster than the soil can absorb it to avoid ponding, run-off, and excessive drainage, and ensure more even soil moisture levels across the paddock. Making sure that the irrigators run with correct speeds, pressures and overlaps will also increase the evenness of water application.

Scheduling irrigation. Once they know how much their irrigation system is applying, farmers can then schedule their irrigation, to avoid under watering and hence losing pasture production, or to prevent over watering, and hence losing water through drainage and run-off. There are commercial irrigation scheduling services available, based on soil moisture measurements. A newer approach is to model the relationship between pasture growth, soil and meteorological data, to enable calculators to be developed to assist farmers to do their own scheduling. One such calculator should be available to Canterbury farmers from next year. 
Using other forage species. Farmers could also consider other pasture types and species which have inherently higher WUEs than ryegrass and white clover. Lucerne is well known for continued growth when moisture stress stops ryegrass and clover growth (Table 2). Other pasture types such as tall fescue are also potentially more drought tolerant. However, productivity of these alternative species needs to be better quantified under commercial situations before clear recommendations can be made for their use on dairy farms.

\section{ACKNOWLEDGMENTS}

Funding for this study was provided by Dairy Insight and the Foundation for Research, Science and Technology.

\section{REFERENCES}

Aqualink 2006. Irrigation efficiency gaps - Review and stock take. Aqualink Report L05264/2. 39pp. Http:// www.maf.govt.nz/sff/whats-on/irrigation-efficiencygaps.pdf.

Armstrong, D.P. 2004. Water use efficiency and profitability on an irrigated dairy farm in northern Victoria: a case study. Australian Journal of Experimental Agriculture 44: 137-144.

Armstrong, D.P.; Knee, J.E.; Doyle, P.T.; Pritchard, K.E.; Gyles, O.A. 2000. Water-use efficiency on irrigated dairy farms in northern Victoria and southern New South Wales. Australian Journal of Experimental Agriculture 40: 643-653.

Bethune, M.G.; Wang, Q.J. 2004. A lysimeter study of the water balance of border-check irrigated perennial pasture. Australian Journal of Experimental Agriculture 44: 151-162.

Cossens, G.G. 1982. The response of pasture to irrigation in central Otago. Invermay Agricultural Research Centre Technical Report 11.34 pp.

Dairy Environment Review Group. 2006. Dairy industry strategy for sustainable environmental management. Dairy Insight, Wellington, New Zealand. Http:// ww w.dairyinsight.co.nz/data/us r/ environment_strategy_full.pdf.

Doak, M.; Parminter, I.; Horgan, G.; Monk, R.; Elliot, G. 2004. The economic value of irrigation in New Zealand. Technical Paper No. 04/01. Wellington, MAF Policy. $62 \mathrm{pp}$.

Fitzgerald, P.D.; Knight, T.L.; Janson, C.G. 1976. Lucerne irrigation on light soils. New Zealand Journal of Experimental Agriculture 5: 23-27.

Greer, J. 1999. Benchmark data on sustainable irrigation indicators. Technical Paper No. 00/08. Wellington, MAF Policy. $61 \mathrm{pp.}$

Hayman, J.M.; McBride, S.D. 1984. The response of pasture and lucerne to irrigation. Winchmore Irrigation Research Station Technical Report 17.79 pp.

Jensen, M.E.; Rangeley, W.R.; Dieleman, P.J. 1990. Irrigation trends in world agriculture. Pp. 31-67. In: Irrigation of agricultural crops. Eds. Stewart, B.A.; Nielsen, D.R. ASA, CSSA, SSSA. Madison, WI.

Linehan, C.J.; Armstrong, D.P.; Doyle, P.T.; Johnson, F. 2004. A survey of water use efficiency on irrigated dairy farms in northern Victoria. Australian Journal of Experimental Agriculture 44: 131-136.

Lynch, P.B. 1966. Conduct of field experiments. N.Z. Department of Agriculture Bulletin No. 399. 154 pp.

Martin, R.J. 1990. Measurement of water use and pasture growth on Templeton silt loam. New Zealand Journal of Agricultural Research 33: 343-349.

McIndoe, I. 1999. Testing of irrigation best management guidelines 1998-99. Technical Paper No. 00/07. Wellington, MAF Policy. 36 pp.

McKenzie, B.A.; Gyamtsho, P.; Lucas, R.J. 1990. Productivity and water use of lucerne and two lucernegrass mixtures in Canterbury. Proceedings of the New Zealand Grassland Association 52: 35-39.

Miller, M.G.; Veltman, A. 2004. Proposed Canterbury natural resources plan for river and groundwater allocation policies and the implications for irrigation dependent farming in Canterbury. Proceedings of the New Zealand Grassland Association 66: 11-23.

Ministry for the Environment. 2004. Water programme of action: water allocation and use. Technical Working Paper, Wellington, Ministry for the Environment. 34 pp.

Morgan, M.; Bidwell, V.; Bright, J.; McIndoe, I.; Robb, C. 2002. Canterbury strategic water study. Lincoln Environmental Report 4557/1. 117 pp.

Moss, R.A.; Burton, R.A.; Morton, J.D. 1996. Borderstrip irrigation strategies for dairying in Canterbury with a restricted water supply. $1996 \mathrm{Pp} \mathrm{13-21} \mathrm{In:}$ Dairyfarming Annual, Department of Animal Science, Massey University.

On-Farm Irrigation Committee of the Irrigation and Drainage Division. 1978. Describing irrigation efficiency and uniformity. Journal of the Irrigation and Drainage Division 104: 35-41.

Parry, F.J.; McKenzie, B.A.; Lucas, R.J. 1992. Productivity and water use of five pasture grasses in Canterbury. Proceedings New Zealand Grassland Association 54: 135-138.

Paton, R.J.; Greenwood, P.B. 1994. Productivity and water use of an irrigated high country pasture. Proceedings New Zealand Grassland Association 56: 159-163.

Penman, H.L. 1948. Natural evaporation from open water, bare soil and grass. Proceedings of the Royal Society of London, A 194: 120-145. 
Rickard, D.S.; McBride, S.D. 1986. Irrigated and nonirrigated pasture production at Winchmore 1960 to 1985. Winchmore Irrigation Research Station Technical Report No. 21. 74 pp.

Wells, C.; Barber, A. 1998. Field testing indicators of sustainable irrigated agriculture study. Technical Paper No. 00/04. Wellington, MAF Policy. 40 pp.

Woodward, S.J.R.; Rollo, M.D. 2002. Why pasture growth prediction is difficult. Agronomy New Zealand 32: 17-26. 